\title{
Foundational Concepts of Military Logistics
}

\author{
Paul C. van Fenema and Ton van Kampen
}

\section{Contents}

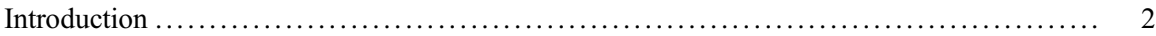

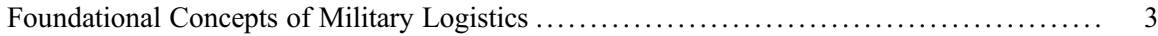

Definition and Relevance ................................................ 3

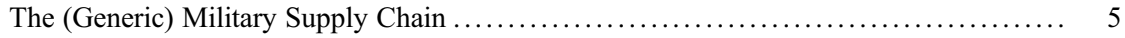

Deep Dive Theme 1: Strategic Alignment and Theater Exit $\ldots \ldots \ldots \ldots \ldots \ldots \ldots \ldots \ldots \ldots \ldots \ldots \ldots$

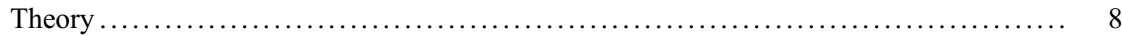

Practice: Doctrine and Learning during the Exit Process .......................... 14

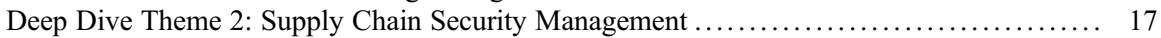

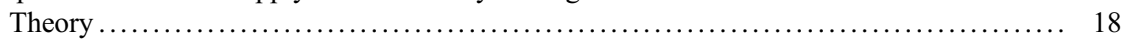

Practice: Embedding Security Risks Management in Logistics Planning .............. 19

Exploring the Future of Military Logistics ........................................ 19

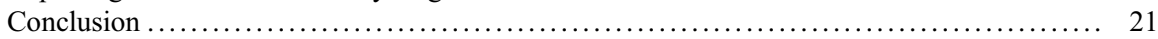

References $\ldots \ldots \ldots \ldots \ldots \ldots \ldots \ldots \ldots \ldots \ldots \ldots \ldots \ldots \ldots \ldots \ldots \ldots \ldots \ldots \ldots \ldots \ldots \ldots \ldots \ldots \ldots \ldots \ldots \ldots \ldots, 22$

\begin{abstract}
Military logistics can be seen as a set of processes that supports military organizations in their development into a capable and functional sustaining military force. Thus, the objective of this chapter is to bring to the forefront and elaborate on some of the foundational premises of military logistics as it is portrayed in its body of literature. To guide this presentation, a generic model is presented which relates logistics' process and structure sides to its generic and mission specific sides. After these generic foundations, two deep dive themes are explored: strategic alignment of resources and logistics management and strategic defense supply chain security management. Recent historic cases illustrate the two themes. The chapter concludes with new ideas on military logistics innovation
\end{abstract}

Both authors contributed to the manuscript equally.

P. C. van Fenema $(\varangle) \cdot$ T. van Kampen

Netherlands Defence Academy, Breda, The Netherlands

(C) The Author(s) 2021 
and draws attention to innovation and performance challenges in the context of military organizations cooperation.

\section{Keywords}

Military logistics $\cdot$ Strategic alignment $\cdot$ Supply chain security

\section{Introduction}

As civilians, we have grown used to a sophisticated portfolio of products that can be delivered at our doorsteps within hours or days at the most (Mangiaracina et al. 2019). Seamless global and local transportation flows connect demand and supply, supported by advanced information technologies. Business-to-business relationships include massive shipments of raw material and (semi-finished) parts to empower production (Schönsleben 2016). While global logistics functions for most of us on the background, natural disasters and pandemics like Corona in 2020 immediately highlight its importance and complex dependencies: "Since China reported the first case of coronavirus to the World Health Organization (WHO) about 12 weeks ago, the arteries of the global logistics sector have begun to clog up" (Khasis 2020).

If we shift our attention to the military, logistics has played at least an equally important role throughout history in this realm of societal activity. Soldiers and their machines cannot fight without constant supplies, at places most of us will never visit. Throughout history, many military leaders had not realized the essence and importance of logistics and failed to appreciate its impact on the battlefield. They paid dearly for their negligence. George Washington in the American War of Independence, Napoleon in Spain and Russia, General Ludendorff in WWI, Field marshal Montgomery in WWII, and General MacArthur in the Korean War are just a few examples of commanders who excelled in combat planning and execution, whose disregard of logistics resulted in grave operational consequences and the loss of the life's of too many soldiers (Kress 2016).

van Creveld argued that technological improvements brought significant changes in military operations. These changes affected the way war was conducted and the inputs that were required for the war-making process. The development of new and effective fire-producing weapons prompted a vast increase in ammunition expenditure, which in turn resulted in a need for many more means of transportation. Moreover, an all-mechanized and motorized army replaced horses, mules, and oxen. Fodder was replaced by vast amounts of fuel, and maintenance meant heaving on hand stocks and special-purpose tools (Kress 2016; van Creveld 2004).

Over the last centuries, distance between the military's operational theater and its home base has expanded as a prelude to massive globalization of trade. A vivid example of the new challenges posed by distance is operation Barbarossa in WWII. On June 22, 1941, Adolf Hitler launched his armies eastward in a massive invasion of the Soviet Union: three great army groups with over three million German soldiers, 150 divisions, and three thousand tanks smashed across the frontier into 
Soviet territory. The invasion covered a distance of two thousand miles and the Germans suffered serious deficiencies in sustaining their troops: Their logistical preparations were grossly inadequate for such a massive and back-breaking campaign; and German industrial preparations for a sustained war had yet to begin. Early December the Germans were stopped at the gates of Moscow. In desperate conditions, they conducted a slow retreat as Soviet attacks threatened to envelop much of their forces in a defeat as disastrous as that which befell Napoleon's Grand Army in 1812. Barbarossa was the crucial turning point in World War II.

One of the best examples of a long-distance network is described in "Moving Mountains: Lessons in Leadership and Logistics from the Gulf War" (1993) written by William G. Pagonis and Jeffrey L. Cruikshank. In record-breaking time, the USA deployed 550,000 troops and 7,000,000 supplies halfway around the world against enormous constrains. As chief logistician, Pagonis was able to form the most effective logistics team ever assembled in the planning, execution, and redeployment of this monumental effort. Lt. General Pagonis succeeded to guarantee delivery of flawless logistical support that could make or break the entire war effort. A responsibility given to him by General Schwarzkopf in person (Pagonis 1993).

The objective of this chapter is to introduce Military Logistics as an academic field and elaborate on some of the foundational premises for military logistics in practice as it is portrayed in its body of literature. Thus, the following section will focus on the foundational concepts of military logistics establishing its purpose in the military organization. Thereafter, military logistics will be elaborated through a closer look at two "deep dive" themes: strategic alignment and supply chain security management. The elaboration on these two themes will seek to display the relationship of theory, doctrine, and insights from military logistical practice.

\section{Foundational Concepts of Military Logistics}

\section{Definition and Relevance}

Speaking across military and commercial domains, logistics is defined as processes of planning, implementing, and controlling for the efficient and effective transportation and storage of goods from the point of origin to the point of consumption (CLM 1998). In the military context, before the modern era, logistics was considered the "practical art of moving armies" (Jomini et al. 2007). Back then, war was about huge numbers of soldiers and basic, disconnected technologies. Military scientists started to realize the importance of logistics to enact strategies and tactics. With technological advances, war and military logistics have co-evolved. In our era, logistics is still defined as the science of planning and carrying out the movement and maintenance of forces (NATO 2014, p. 2-L-5). Yet it has come to encompass several interdependent activities geared towards people and weapon systems. This leads to an extended definition of military logistics as activities required for: 
- Acquiring military organizations' physical goods (supply chains, military mobility) and weapon systems, and hiring people, administrating, and moving these towards, within and out of a theater. Goods, people, and systems could refer to contractors' services delivering desired functions.

- Accommodating the military all over the world (facilities and services for people and weapon systems).

- Making sure soldiers and future weapon systems receive and can use relevant commercial and military technology for their job (technology management and maintenance). These technologies are increasingly intelligent and networked, think of hybrid warfare (Hoffman 2009).

Even in the era of cyber and information warfare, logistics remains relevant with respect to human warfighters and physical resources. While logistics enables commercial businesses to outperform competitors on service and costs, that is, a focus on profitability, the objective of military logistics is "to comply to the best compromise regarding users' demands with acceptable costs and capital use" (Wijbenga 2019). Resonating the introduction chapter's distinction of hot and cold domains, the perspective of military logistics comprises both peace-time logistics and support to on- and off-shore operations, planned or unplanned (Gallasch et al. 2008). It must establish, organize, and run lines of supplies ("lines of communication" in military jargon) such that armies can move and fight, including real life support and maintenance. The primary objective of military logistics - depending on strategic and operational requirements - is to enable and sustain a specific state of readiness for war, i.e. fighting power, at the lowest possible overall cost.

Fighting power is the ability to conduct military operations in an optimum cohesive totality of functionalities and components. It is more than just the availability of means (capacities); there must also be the willingness and ability to deploy these means (capability). (Use of the term capability the concept of routines in business literature (Makadok 2001).) If this is properly developed, it then becomes fighting power, and capacities are elevated to capabilities. Logistic support is essential in realizing and sustaining the operational use of materiel: the assured supply of fuel, spare parts, ammunition, food and medical supplies to the training or deployment area is often critical to the success of a military operation (MoD 2019).

Once an operation has begun, the deployed force must be able to sustain the operation as long as is necessary to achieve the desired effect. To guarantee the sustainability of an operation, all the required conditions must have been met. Logistics deliver a vital contribution to sustainability; the latter term is not directly related to sustainability as in reducing harm to the natural environment. The sustainability function entails support with the materiel, personnel, and financial means required to build up and maintain fighting power. A logistics plan based on the operation is also essential for the realization of the objectives. Any deployment without a logistics plan based on maneuver, fires and force protection is doomed to failure (MoD 2019). Logistics preparation must, therefore, be included from the start of the planning process. 
So, the metric for military logistics success is readiness, not profit (Burns et al. 2010). More specifically, military logistics is required to operate in a cost-efficient mode during peacetime, but then - often at very short notice - it must transition to a posture in which effectiveness is paramount and cost a secondary consideration. Recent experiences with the Corona virus offer vivid examples of such scaling up. After all, while business competition tends to grant competitors second chances, a military conflict does not come with this luxury.

\section{The (Generic) Military Supply Chain}

Military logistics support defense organizations' main value creation processes of ensuring combat power elements, preparing combat power, and enacting it (i.e., missions). Figure 1 shows a framework of Defense value creation and Defense logistics, offering a strategic concept for structuring activities. The framework combines common Defense value chain and logistics concepts (de Bakker 2012, p. 552; MoD 2015b). The upper half depicts three main value creation processes constituting Defense value creation. The main value creation processes materialize

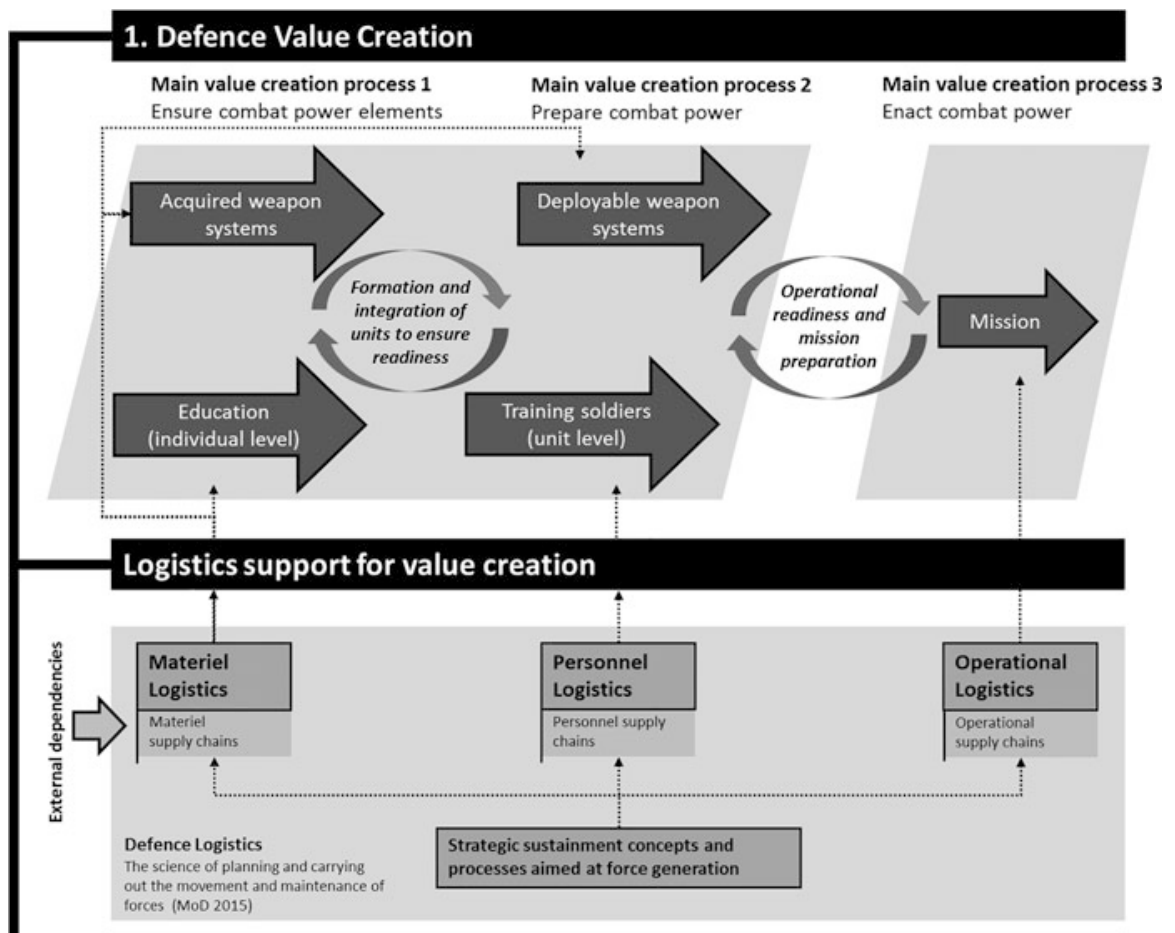

\section{Defence Logistics}

Fig. 1 Defense value creation and defense logistics framework 
the constitutional stipulations for the defense organization. Combat power depends on eight elements: leadership, information, mission command, movement and maneuver, intelligence, fires, sustainment, and protection (USArmy 2011). To this end, (trained) people and (deployable) weapon systems are required (de Bakker 2012). The required logistical support focuses on personnel, materiel (including stockpiling), and operations. Materiel logistics, then, can be understood in a limited sense (focused on equipment) and in a broader sense (products and services required for force generation excluding personnel logistics).

Operational logistics (Fig. 1, bottom right) stretches across a network of nodes with multiple processes, through which personnel and materiel - equipment and supplies - flow and services are provided to a deployed force. A military supply chain is designed as a flexible set of supply chains connecting points of production and use, ensuring the most appropriate and efficient use of resources across all its nodes, maximizing information and technology to assure logistic support to operational commanders (MoD 2015b, p. 9). A military supply chain is specifically tailored (i.c. aligned) to the characteristics of the operation. By using different modes of transport - that is, air, sea, rail, and road - the operational supply chain comes into action.

Figure 2 shows a mission-specific logistics structure (black box, right hand "structure" column of Fig. 2). The left-hand column shows processes pertaining to logistics. The two columns reflect the structure-agency debate in organization sciences (van Fenema and Keers 2020). Vertically in Fig. 2 we distinguish and relate a generic level (top) and mission levels; the latter in the sense of an "edited" format and "evolving experience." Across the columns and levels linkages are depicted with rounded arrows.

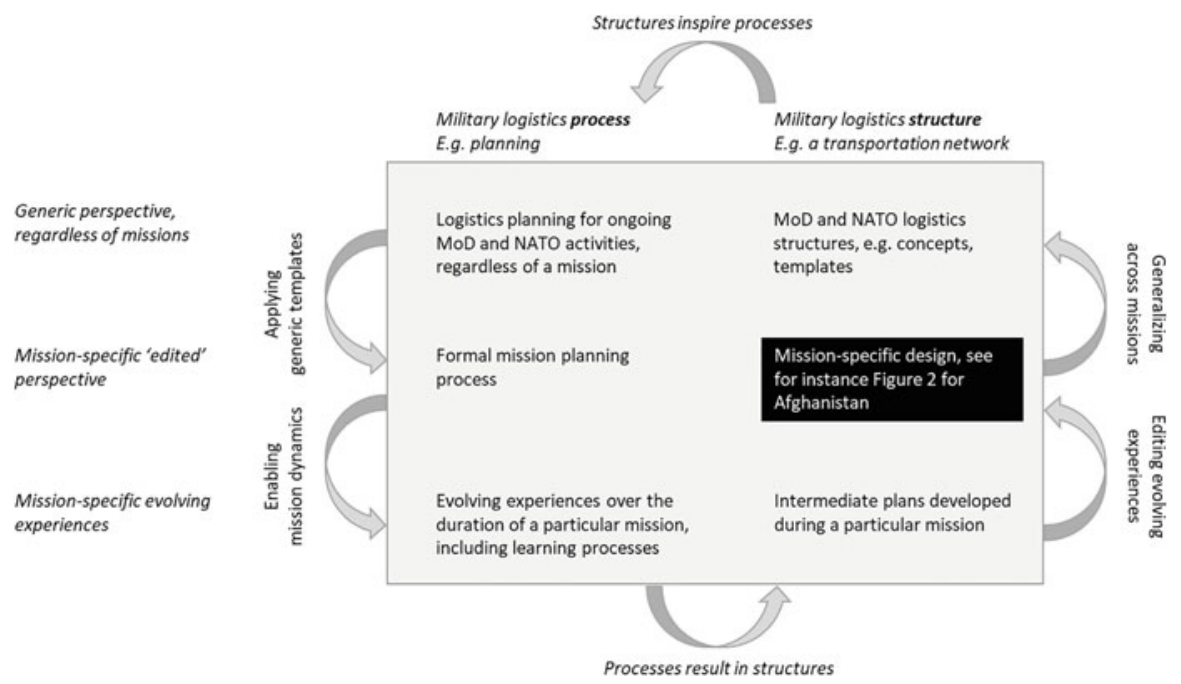

Fig. 2 Military logistics processes and structures 
To better understand the intricacies of logistics supply chain networks, we elaborate on two deep dive themes. Our first foundational and elaborate theme explores strategic alignment to link military logistics to military value creation. Our second shorted and specialized theme concerns security management. The Afghanistan example illustrates creation of a complex supply network due to security risks and operational uncertainties.

\section{Deep Dive Theme 1: Strategic Alignment and Theater Exit}

The relationship between operations by which an organization creates value and logistics has been a pivotal subject in business and military logistics literatures (Kress 2016; Stank et al. 1999). Phases of a mission need to be timely planned, carefully prepared, and perfectly executed. Responsibilities must be clearly defined, and the physical execution must be done by logistical experts because of the required skills and specific knowledge. Since many stakeholders are involved, strategic alignment is essential during executing. Only under these conditions unnecessary costs can be avoided, necessary contracted labor can be limited, and no expensive resources are being wasted. We explore theory and practice of strategic alignment, both tied to the process of exiting a theater as a complex situation the military struggles to deal with.

\section{Theory}

Strategic alignment emerged as a conceptual phenomenon in the early 1990s. Researchers started to examine the relationship between theorizing on organizations' competitive (business) strategy (combinations of mass versus niche market and differentiation versus costs focus) (Porter 1998; Speed 1989) and the strategic role of Information Technology (IT) (Henderson and Venkatraman 1992). Building on this stream of research, we read logistics for IT as another supportive organizational function. Hence, strategic alignment refers to the degree to which a primary process (here: political-military processes) is supported by and supports an enablingsustaining process (such as IT, logistics, facility management) (Sabherwal and Chan 2001). This cyclical view, echoed in operational military logistics scholarship (Kress 2016), allows for theorizing on how decision-making dovetails with logistics and resources processes ("supplier"), and how the latter processes can be of value to political-military stakeholders (“customer"). Figure 3 provides an overview which we elaborate on.

Literature demonstrates a wide variety of missions and shows the dynamic nature of these missions as they proceed and come to an end. In this versatile environment of conflicts, resources play a pivotal role. Resources in the theater - belonging to the internal and external actors present in the theater (Sinno 2008) - vary as well in terms of quantity and quality; this also applies to logistics as an enabler of resource management. Resources encompass military and civilian assets; in this chapter, 


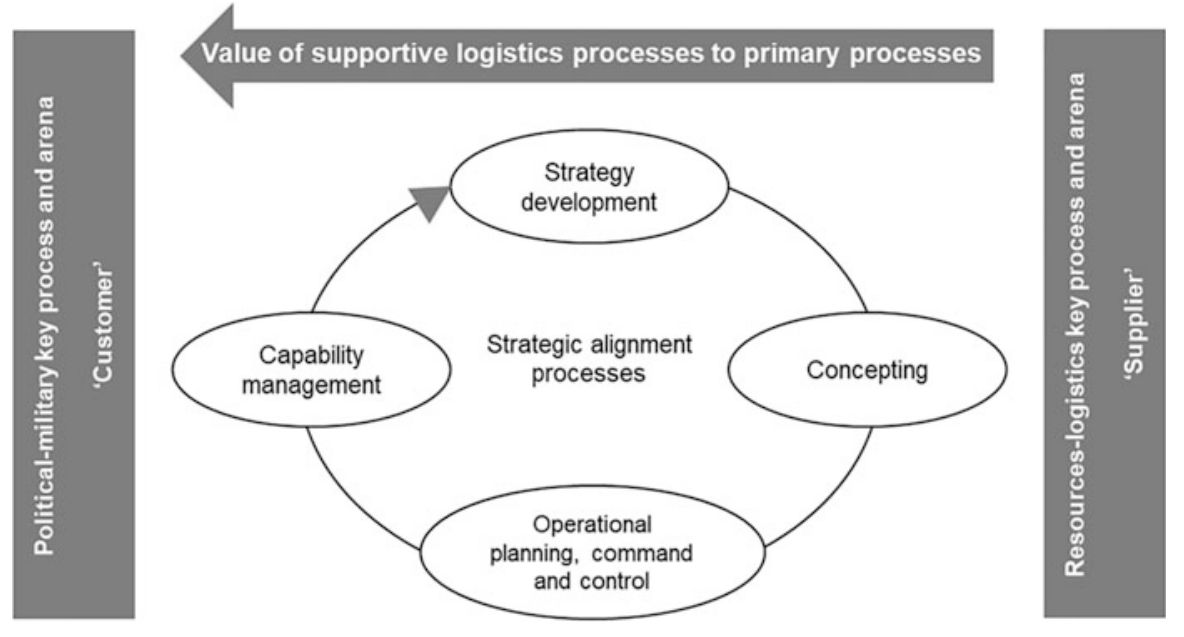

Fig. 3 Strategic logistics alignment framework

natural resources originating from or required by the theater are not considered. Moreover, more civil resources and new logistics concepts may be required to cater to the new demands of the operational phase. In general, logistics should be aligned with the specific properties of the type and phase of a mission (Kress 2016).

While resources and logistics could be approached at an operational level, we include the strategic level as is common in nonmilitary supply chain management (Hulsmann et al. 2008). Missions, after all, are embedded in long term strategies of actors involved in or affected by a mission. Two major arenas of actors should be acknowledged (Scholtens 2008): political-military and resources-logistics. The alignment relationship between these actors' arenas is dynamic. Current literatures on alignment (Chan and Reich 2011) adopt a process perspective to understand the dynamic interplay and evolution of intersecting processes. This paragraph explores how political-military and resources-logistics arenas intersect in a dynamic manner. Generic notions from literature are presented to build the alignment framework.

At the center of Fig. 3, we show four processes constituting strategic alignment, each pertaining to the customer and supplier.

\section{Process 1: Strategy Development}

In relation to military logistics, Customer Strategy Development refers to the political-military strategy development which is understood here as formulating long-term objectives for a particular theater. These may partially conflict with those held by intra- and extra-theater actors. For instance, theater politicians seeking rapid exit versus politicians from abroad being concerned about longer term influence; or rapidly organizing exit versus continuing some vital mission activities. Such objectives articulate long term abstract ideals, for example, "bringing a democratic 
government to Haiti" (Strednansky 1996). These abstract statements need approval of multiple actors to ensure their mandating (Zaum 2012), and they need operationalization.

On the other hand, Supplier Strategy Development depicts the supplier's strategic perspective. Operations are about influencing a theater; they demand resources and logistics to be sustained, in particular when the military operates in a geographical theater abroad. At the strategic level, organization of resources and logistics ideally reflects the articulation of political-military objectives in a coherent manner. That is, features of political-military objectives are translated into value driving features of resources-logistics processes. This translation process is similar to supply chain strategies matching business strategies in a commercial environment (Perez 2013).

In a commercial setting, predictable demand leads to efficiency-oriented supply chains; unpredictable demand - for example, innovative products - requires supply chains aimed at effectiveness (Selldin and Olhager 2007). For military missions, translation of military-originating requirements into strategic resources-logistics value drivers resembles this commercial example. Specifically, two sides of resources-logistics strategy development can be distinguished in commerciallogistics literature: external logistics performance and internal logistics efforts (Van Goor et al. 2019). Externally, they are aimed at achieving "customer" (i.e., political-military) objectives, which refers to service levels in business terms, for example, how quickly are products made available. "Internal" concerns the resources-logistics processes themselves, focused on delivering such performance at lowest possible costs. The better customers are served and the lower the costs, the more value resources-logistics processes add. In the military, customers are politicalmilitary stakeholders. The external dimension of resources-logistics processes refers to them. Internally, costs may not be the primary criterion for military resourceslogistics processes. Availability is a key concern for commanders, for instance, rather than costs.

\section{Process 2: Concepting}

Customer Concepting It refers to generic, in a military sense doctrinal, conceptualization of military operations and logistics, regardless of planning for a specific mission (phase). Past missions have yielded a myriad of concepts that can be used to understand, configure, and enact (phases of) operations in a specific theater. They increasingly capture the continuum between war and peace. Concepts, including approaches or methods, range from warfare to operations other than warfare, for example, peace support operations, integrated or comprehensive approach on the topics Defense, Diplomacy and Development (3D), "peacemaker method," Provincial Reconstruction Teams (PRT), Counter Insurgency (COIN), and policing (Strednansky 1996).

Concepts consist of evolving sets of features or principles (Alvesson 1998; van Fenema and Keers 2020), such as combined arms (Moten 2010), or "go small, local, and long" for missions like Afghanistan (Gartner and Blanken 2012). Historic 
examples suggest that concepts provide a rough outline of what is going on. Misestimates and misrepresentation have frequently occurred, such as "going light" during initial UN operations (Brahimi 2000), and framing Afghanistan as a peace support operation when security remained problematic (Gans 2019). This represents an important phenomenon. Sometimes, the political arena seems to call for a particular conceptualization to obtain political support, sometimes lessons from earlier missions are not applied, and sometimes the complexity of theater events prevents (agreement on) clear conceptualization.

Supplier Concepting Resources-logistics concepts refer to, for instance, support concepts with associated organizational structures, (location and size of) stocks, physical flows, information processing, contracts, and the role of contractors (Leblanc 2008). Their features may vary from centralized to decentralized, autonomy or self-supporting versus outsourcing, military versus civilian, and light versus heavy. The value impact of resources-logistics concepts, that is, their relevance, depends on the extent to which they match strategic objectives pertaining to resources-logistics. Ideally, a concept matches key elements of strategic objectives. As mentioned, value concerns the external catering to customers' value drivers while lowering internally the costs of resources-logistics processes. Concepts cover responsibility distribution across different levels of organization (Leblanc 2008).

In military organizations, doctrinal concepts have been developed and adjusted, providing some clarity and commonality in the way military organizations' own professionals and their counterparts work (Futrell 1989). Concepts are selected depending on their usefulness for resources-logistics strategies pertaining to a particular theater. For instance, airborne supplies, though costly, may be appropriate under time pressure and adverse geographical or security conditions. And private contractors may fit in a concept for supporting prolonged presence of troops without military organizations' resources deployed. Increasingly, resources-logistics concepts involve international military cooperation and private contractors. This way, cooperation synergies can be utilized, and troops and their military organization can focus on the core mission.

\section{Process 3: Operational Planning, Command, and Control}

Customer Operational Planning, Command, and Control Planning and control operationalize the former two dimensions strategy development and concepts. Researchers propose rational and political approaches. From a rational-engineering angle, researchers emphasize the role of clear and consistent metrics that can show when desired conditions have been achieved (Innocent and Carpenter 2009), and enable meaningful measurement of outcomes rather than inputs (Caplan 2012). Actual data from the theater can be offset against these metrics (or "anticipatory indicators of success" (Gartner and Blanken 2012)). At times, strategic objectives remain vague, making measurement impossible (Zaum 2012). 
Those favoring or emphasizing political approaches, on the other hand, raise concerns about the "value judgments, assumptions or prejudices built in to the very choice and articulation of indicators" (Farrall 2012). Showing progress may bear political relevance to the supporting nations' and theater-based public and political system (Caplan 2012). The role of past experiences could receive only scant attention. Moreover, capturing the complexity of theater dynamics would take more than a limited set of indicators and associated data processing. Foresight would be required involving a myriad of actors (Richardson 2009).

In addition to these rational and political approaches towards performance, researchers stress the varied nature of performance, that is, military and civilian efforts befitting "whole of government" approaches (Caplan 2012).

Finally, planning and control require organizing: which organization has responsibility for what, how are roles divided? Who sets priorities to allocate (often insufficient) resources (O'Hanlon and Sherjan 2010)? Contributing actors from inside and outside the theater will have their own planning and control cycles. Inevitable "interagency squabbles" (Fukuyama 2004) and turf wars have to be sorted out. No single actor has a complete overview and all-inclusive capacities (Reiter 2009). Some actors may specialize in particular aspects of planning and control, such as military or civilian efforts. Network structures are required to connect actors; they call for political commitment, dealing with cultural diversity and figuring our mandates of and contributions by participating actors (WP 2009). These could be decentralized or (somewhat) centralized by means of a lead agency. Such an agency, typically not a national Department of Defense (Fukuyama 2004) but, for instance, an UN agency, "act(s) as a point of contact for other agencies, particularly in the areas of planning and information-sharing" (Flavin 2007). It can facilitate interaction among actors aimed at planning and control. With respect to exit planning and control, early efforts may be useless due to changing circumstances (Caplan 2012). Moreover, actors need to bear in mind the fragile nature of peace and the likelihood of postexit efforts (Caplan 2012; Strednansky 1996).

Based on strategic alignment and planning, command and control rely on metrics to coordinate activities. In order to control, these are offset against information from the theater. In a complex theater such as Afghanistan, this proved cumbersome: "The current situation on the ground has proven so fluid and poorly measured as to be almost impossible to characterize with any degree of certainty" (Gartner and Blanken 2012). Multiple military and nonmilitary actors are involved in the command and control processes during all phases of a mission.

Supplier Operational Planning, Command, and Control In coordination with planning and control for political-military processes, military and civilian actors plan their resources and logistics flows. Planning is as an activity that connects political-military and resources-logistics processes. It has been generally defined as "working out in broad outline the things that need to be done and the methods for doing them to accomplish the purpose set for the enterprise" (Mintzberg 1981). While this definition applies to the enterprise level, we consider this concept for a mission. Planning, then, is a process of translating strategic objectives into a funded, 
workable, resourced, and logistically feasible set of ideas for organizing action. For military operations and their expected objectives, sufficient resources have been noted as a major concern (Innocent and Carpenter 2009). Plans may represent an ideal situation that lacks adequate sources (Innocent and Carpenter 2009; O'Hanlon and Sherjan 2010). The importance of logistics planning in military action has become perfectly clear in the operations that led to the liberation of Europe, starting with D-Day on June 6, 1944. The landings in Normandy and the following supply chains had a large influence on the success of the allied operations. To stop the ceaseless supply of allied stuff, and to split the Allied lines, Nazi-Germany launched a desperate counteroffensive to regain the port of Antwerp in the winter of 1944/ 1945 - the so-called "Battle of the Bulge." This counterattack failed not because of a lack of fighting spirit or fire power on the Nazi-side, but because of an inadequate supply of people and material resources, in particular fuel and ammunition. The attack simply stopped because after a few days there were no more supplies for the Nazi-troops on the right place at the right time. A counterattack to stop successful logistics failed because of unsuccessful logistics planning. Planning has not only a (traditional) professional-technical flavor; it also reflects assumptions in a political sense and in the sense of dealing with the ambiguous impacts of planned actions in the theater. Historic examples show the complex nature of planning as a form of coordination that precedes an operation (Moten 2010). And its indispensable role and challenge of making realistic estimates for different operations, for example, overestimating own capabilities and underestimating those of an opponent (Johnson and Tierney 2011). Militaries invest in synchronization of their common operational picture with their common logistical picture. This also concerns criteria and priorities for decision-making in these two realms. Theater logistics involve both strategic transportation and intratheater logistics. Planners have to deal with geographical and infrastructural properties of the theater, including entrance routes (O'Hanlon and Sherjan 2010). Increasingly, enabled by IT, resources, and supply chains in the commercial world become more visible in the sense of knowing what is where, what the condition of assets is, and how long physical flows will take (Wang and Wei 2007). These approaches start to be introduced in military organizations. Analysis of patterns adds to organizations' ability - across units active in the same theater (Leblanc 2008) - to report on, predict, respond, and adjust resources-logistics processes, for example, equipment wear and tear (Hampapur et al. 2011; Leblanc 2008; Maas et al. 2014). Coordination of resource decisions with resources-logistics planning beyond a mission can underpin higher overall performance levels. This results from balancing across theaters and coordination with international actors' home-base requirements for equipment. While visibility and analytics tend to be developed at the organizational level, network-level efforts would pay off to leverage economies of scale. Planning and control demand attention to balancing issues, such as how to deal with scarce logistics capacity. 


\section{Process 4: Capability Management}

Customer Capabilities Finally, political-military processes draw on deployable capabilities to achieve their objectives. Capabilities refer to coordinated practices and materiality and represent constituents of (military) power (Reiter 2009). The military has been used to frame their tasks and resources in terms of high-level capabilities, for example, airlift, manpower, and firepower. While attempts are made to generate (high level) capabilities at the network level, research suggests, capability management at mission level tends to present a challenge to UN and NGOs as they lack (authority over) resources (Strednansky 1996). Current missions call for a diverse set of capabilities to influence the theater. Increasingly, this set encompasses nation building capabilities (Sigal 2007), media capabilities for communicating with the public (Tuck 2004), capabilities to attract international support for the mission (Filson and Werner 2004), and cyber capabilities. The role of capabilities depends on for instance the theater's public, threat of opposing forces, and mission phases (Reiter 2009). Capabilities as a notion can be interpreted as a political-military topic (obtaining agreement on use of capabilities) and in physical terms (i.e., actually being able to perform the capability) (Whalan 2012).

Supplier Capabilities Alignment of resources-logistics processes with politicalmilitary capabilities is important. Research suggests room for improvement, in the sense of anticipating requirements for resources and logistics. "The emphasis on logistics in future operations must come earlier, and must include a simultaneous rebuild of strategic level sustainment capabilities (i.e., "supplier" capabilityauthors) with the theater security capabilities (i.e., "customer requirements for resources and logistics based on their political-military required capabilities" authors)" (Leblanc 2008). Missions draw on multiple actors to provide such capabilities. Nations decide more and more on services they want from or deliver to other nations, NATO, and contractors. This improves economies of scale. Capabilities required for external value delivery (i.e., to customers of resources and logistics) are being sourced in part from outside the military organization (Davids et al. 2013) rather than - as has been a military tradition - striving for autonomous resource management and supply. As IT permeates the military realm, organizations strive to gain instant access to physical resources and flows; capabilities can be precisely tailored. In practice, the impact of these innovations remains to be seen given the commonly complex and volatile nature of exit phases. For international military actors, strategic transportation and in-theater wear and tear present palpable challenges for extended involvement in a theater (Strednansky 1996; van Kampen et al. 2012). Sophisticated asset management capabilities - in cooperation with commercial suppliers - are called for to keep assets available in taxing environments. Network cooperation can be used to provide a pool of strategic transportation assets. 


\section{Practice: Doctrine and Learning during the Exit Process}

While much research has explored starting and managing a mission (de Leeuw et al. 2012; Kapucu and Garayev 2012; van Fenema 2010), the final phase has received scant attention. That is why we seek to understand its dynamics as an example of strategic alignment challenges. The dynamic nature of exit phases calls for adaptation of organizational processes and learning from experiences in the theater and previous missions. As earlier elaborated, exit represents a specific phase of a mission compared with deployment (i.e., deciding on a mission) and sustainment (finetuning during a mission). In general, learning within the theater depends on "information gathering mechanisms, centralized field coordination, experienced staff distributed over the field, and capable leaders. Additional preconditions include the supply of well-trained and well-equipped troops in adequate numbers and requisite funding" (Howard 2008). Ideally, towards the end of a mission, organizations have learned a lot about the interplay of political-military and resourceslogistics processes. Moreover, insight in theater and how actors respond to interventions has been expanded. Yet how the theater responds and participates in an exit process remains unknown.

At the end of an operation, it would be unusual, and possibly a sign of strategic failure, if a nation's defense forces were withdrawn without a progressive reduction of force levels and a staged drawing down of equipment, inventory and other materiel, infrastructure and people. However, that is not to say that logistic planner are likely to have all the freedom they desire to achieve a carefully planned and managed drawdown and withdrawal from theatre; for example, the withdrawal of UK, US, and other coalition forces at the conclusion of the 1991 Gulf War was to a large extend shaped and influenced by cultural sensitivities and the need to have completed the bulk of tasks before the Ramadan (J. E. Smith 2018).

With hindsight, concepts emerge that seem to work in a current operation or previous ones, e.g. reusing the COIN principle "going small and local" from Vietnam in Afghanistan (Gartner and Blanken 2012). These concepts that apply to an entire mission could be refined for their exit phase. Organizations could learn how to back up these concepts with required resources and logistics. This parallel learning in resources-logistics in conjunction with learning in the political-military area seems of interest and warrants more research, in particular with respect to exit. We examine doctrine and actual experiences.

\section{Doctrine}

During a strategic exit, a lot of stakeholders are involved from inside and outside the theater. For instance, decision makers on the political and military dimensions of exit and military and contractors involved in logistics and resource management. Hence, it is of outmost importance to have a common understanding of the conceptual framework of a strategic exit. Unfortunately, there is no actual doctrine on strategic exit or redeployment from operations. The written instructions and guidance on strategic exit are outdated and not concentrated within a single doctrinal publication. The strategic exit of forces from a theater must be accomplished in such a way as to 
support follow-on operations or a renewal of combat. How to plan for the exit or deliberate disengagement of forces while in contact is therefore a crucial element of operational planning and must be viewed as the final act of any campaign (USArmy 2012). Because of the risks, strategic exit need to be prepared and executed as a unified military operation. During an exit, both personnel and equipment are vulnerable to enemy attacks (Boyd 2015). Exit needs to be part of the overall campaign plan. Strategic exit is the last phase in this plan with a clear focus on re-establishing unit integrity and accountability of personnel and equipment. According to the doctrine of the Netherlands Army, this strategic exit phase, involving redeployment, is executed in several phases, representing a linear-sequential approach $(\mathrm{MoD}$ 2015a). There are three basic disposition options for drawing down equipment: (1) returning it to inventories outside the area of operations, (2) transferring it to another agency or the government of another country, or (3) destroying it. Transfer to other entities, such as state governments by means of donations or sales, may also be possible.

\section{Cases}

Three examined cases on strategic exit - Kosovo, Iraq, and Afghanistan - of Dutch and US Armed Forces proved challenging and presented similar issues. Logisticians faced the huge challenge of re-establishing property accountability, inventory control, and supply discipline after years of conducting military operations. Gaining accountability of the property is the first step to understanding the challenges associated with withdrawing forces. As Lt. Gen. Mason stated, "Leaving Afghanistan has become one of the most difficult operations the US military has ever undertaken. It's the biggest operation in terms of complexity, seize, and cost" (Boyd 2015). Three lessons were learned on strategic exit:

1. Command and control. Because there are a lot of actors involved during an exit, it is of utmost importance to have a clear command and control structure (unity of command) in which tasks and responsibilities are completely unambiguous registered. During the Kosovo, Iraq, and Afghanistan withdrawal, there was no clear command and control structure although some significant progress was made. The lack of a clear command and control structure also leads to an inefficient use of assets.

2. Accountability of Government Furnished and Theater Provided Equipment. Nowadays it is almost unthinkable that a coalition of military forces can deliver all logistic services by itself. More and more contractors are used to support the military units. The Dutch armed forces also used contractors for (rotary wing) transport and other logistic services such as the supply of fuel and food to the different bases. Using contractors on such a large scale was not always a success especially on the subject of Government Furnished Equipment. Future contracts must be written such that they require all entities performing services of the army, controlling government equipment, to utilize army property accountability systems. Also, contractors provided with GFE must be held financially liable for such equipment to the same standards as units. Additionally, probably the biggest 
issue concerning strategic exit is re-establishing property accountability and inventory control over theater provided equipment after years of conducting military operations. While originally designed to simplify the logistics of deploying units by reducing the amount of equipment shipped into and out of the theater of operations, the use of TPE created additional challenges. Both US and Dutch armed forces learned hard and very expensive lessons on this subject. In future operations, property handed from one unit to another should be transferred to existing property books. Maintaining separate property books for TPE and unit equipment is duplicitous and unwanted. Maintaining property accountability is far easier than re-establishing it once lost.

3. Visibility concerns container management and Intermediate Staging Base (IBS). The managing of shipping (commercially owned) containers has been a longstanding challenge for both US and Dutch armed forces, a challenge that is particularly acute during this type of contingency operation because of the huge number of containers involved. To solve the problem of container management, the Dutch DOD developed a stand-alone fleet management system for containers (derived from Mission Specific Logistic Instruction ISAF, 12th July 2013). The most significant difference between the war in Iraq and the one in Afghanistan was having Kuwait as an ISB to receive and stage the retrograde (Banian 2013). The good road network leading directly to Kuwait provided operational flexibility by enabling the command to retain up to half of its maneuver force in Iraq until the final withdrawal in the Fall of 2011. In contrast, Afghanistan is landlocked, has primitive road networks, is covered with extremely challenging terrain consisting of high mountains, and experiences strong weather conditions. None of the neighboring countries allow easy access or are willing to serve as an ISB, which decreases flexibility and increases cost, complexity, and risk to meeting time constraints. To conclude the cases, all lessons learned examples illustrate the challenges associated with conducting a strategic exit from a theater after a long duration campaign. While technological innovations have improved the ability to provide better visibility of movements and aid in planning retrograde operations and reconstitution efforts, the tasks associated with a successful exit remain daunting and require thorough preparation. Planners at the operational level must recognize that planning for a strategic exit of forces must involve more than just the logisticians in an organization.

\section{Deep Dive Theme 2: Supply Chain Security Management}

Our definition of military logistics depicted multiple interdependent practices: arranging for input of people and resources, processing these and ensuring their availability, and usefulness for operations. This interdependence usually spans geographical distances as well, with an industrial base supporting a military operating elsewhere. A tension - contradictory requirement (W. K. Smith and Lewis 2011) - can be noted between the interdependent nature of logistics practices (including their external vulnerability on the input side), and the extreme, possibly prolonged, 
demands of operations. Military practitioners and academics have repeatedly mentioned their awareness of this tension (Lindley-French and Boyer 2012; van Creveld 1979). Our second deep dive therefore concerns supply chain security management. The section is based on a more extensive and specialized chapter on supply chain security management (van Kampen et al. 2016).

Major crises such as the current 2020 Corona pandemic have revealed a lack of preparedness of supply chain (SC) managers towards disruptive events (Sheffi and Rice Jr 2005). Such crises may have intentional (realm of security) or unintentional (natural disasters or pandemics) origins and induce various types of risks affecting supply chains. Given our focus on military logistics, we limit ourselves to risks stemming from security concerns (van Kampen et al. 2016). Security should be part of SC design and management processes, transportation hubs, and flow of goods and people.

This is far from new. Already in the Middle Ages the French King Charlemagne developed a logistic system that included a supply train that held enough supplies and equipment for several weeks campaigning, fortified depots along the line of march, and lines of supply that were protected by strongholds in frontier areas (burgs). This enabled him to campaign for extended periods of time up to 1000 miles from the center of France and maintain armies in the field or in a siege during the winter, a feat almost unknown since the end of the Western Roman Empire. The poor logistics of Frankish armies up to that time meant they could not project military force very far and usually dispersed after only a short period (J. E. Smith 2018).

For the most part, researchers have examined security as a generic concept in the commercial world (Hameri and Hintsa 2009; Natarajarathinam et al. 2009). But what does security mean for military supply chains? We explore theory and practice of security risk management in defense supply chains.

\section{Theory}

Supply Chain Security Management can rely on risk management (approach 1) or adaptive capability (approach 2). We present these as alternative approaches since they reflect different logics (Thornton and Ocasio 2008). The former takes a supply design (structure) for granted and then explores risks (think of exploitation in ambidexterity theory (Simsek 2009)), the latter puts entrepreneurial agency center stage (exploration). Military organizations often harbor specialized units that enact these two approaches.

Risk-Based Supply Chain Security Management (Approach 1). SC security concerns protection of supply chain assets from threatening human agency and to keep supply chain activities separated from illegal human agency (Closs and McGarrell 2004). SC risk refers to the likelihood of SC outcomes being susceptible 
to disruption (Closs and McGarrell 2004). The process for managing SC security is called SC security management (SCSM), which serves as a means to prevent and mitigate SC security risks, while the more comprehensive process of managing SC risk is known as SC risk management (SCRM). SCRM reduces SC vulnerability by careful planning (Markmann et al. 2013). SCSM, as a subprocess of SCRM, seeks to prevent or counter threatening actions such as damage (Markmann et al. 2013).

\section{Supply Chain Security Management and Adaptive Capability (Approach 2)}

While the former approach provides an organization with a framework for understanding SC security risks and taking measures, it lacks insights in adaptive capabilities (Seifert and Langenberg 2011). For major crises, a more entrepreneurial approach to security management is warranted. The necessity to invest in an adaptive capability depends on the strategic urgency of SC and the likelihood of major crises (Nilsson and Waidringer 2004). Strategic urgency relates to the importance of items to military operations and external availability. It may increase when military end users of the supply chain have limited alternatives for the products they use and/or when the supplier base offers limited possibilities for switching. Increasingly, military organizations attempt to foster their adaptive capabilities at the network level (Flavin 2007).

\section{Practice: Embedding Security Risks Management in Logistics Planning}

The military puts a lot of effort into the logistic planning, including security (van Kampen et al. 2016). SCSM starts as part of a comprehensive and detailed logistic planning process (see also left-hand column in Fig. 2). We first present an overview of the generic military logistic planning process (A). As part of this planning process, the (operational) SC planning is elaborated upon (B), followed by security risks management to assure logistic support (C).

- (A) Generic Military Logistic Planning (NATO 2010, 2013). Effective operational logistics is essential for military operation or mission. It requires a shared comprehensive understanding of the operational situation, starting at the beginning of the planning process. Early in the planning process, the Logistic Operational Planning Group Team (LOPGT) lacks the required information to design the "best" SC plan. (DOPS/J4 is in the lead of the LOPGT within Dutch MoD) LOPGT can refine however during the subsequent stages of the planning process, including addressing risks - both safety and security.

- (B) Operational Military SC Planning. The logistic planning process (A) can be transformed into a generic SC planning model (MoD 2015a, p. 7), see also the generic level in Such a model encompasses the sequence of activities of the planning process. The UK Defense Equipment and Supply (DE\&S) Department (MoD 2005) developed a generic SC planning model (Fig. 4), underscoring the need for operational SC plans to ensure that the supported commander's demands 


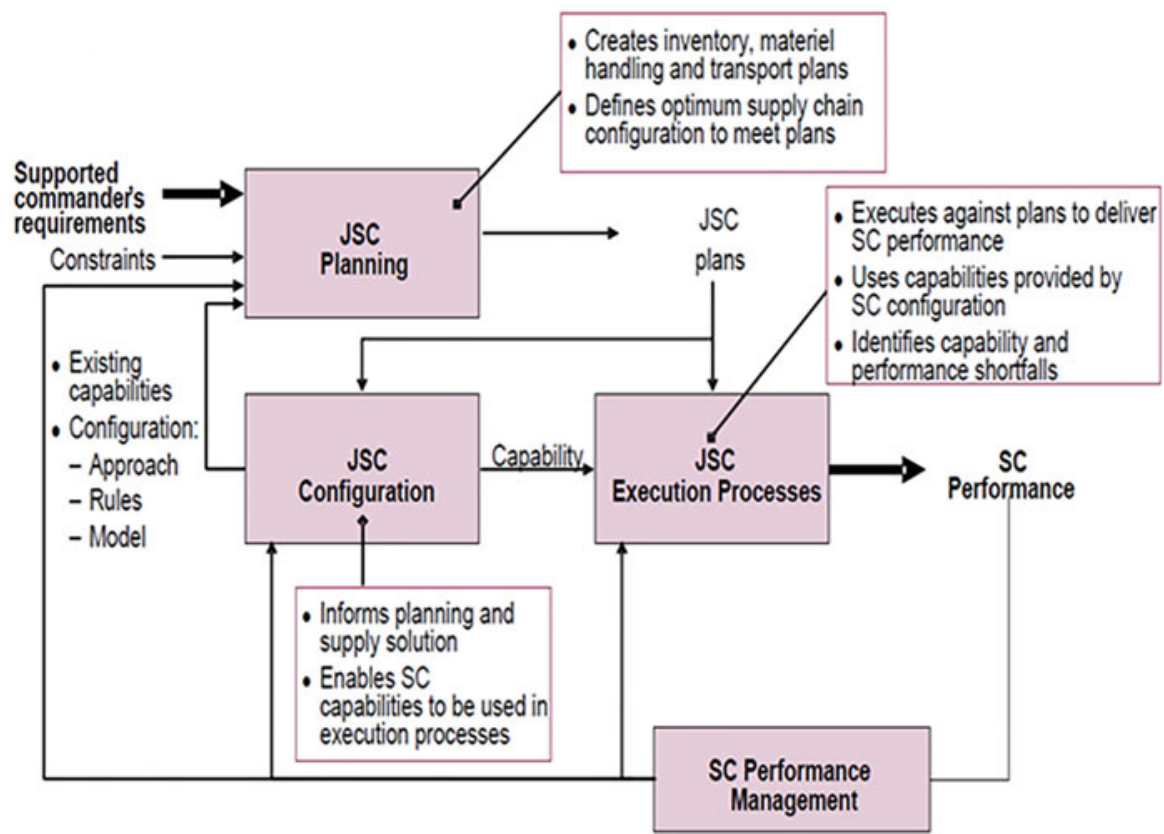

Fig. 4 Core activities essential to achieving a reliable and effective SC planning (MoD 2005, p. 15)

are addressed (i.e., assured logistic support) (MoD 2005, p. A-23). The iterative model can be used under various levels of time pressure and it includes SC security risk management.

- (C) Operational Military SC Security Risk Management (NATO 2013, pp. 3-56). Effective security risk management (approach 1) is important at every level of planning (MoD 2005, p. 44). Proactive adaptive capabilities (approach 2) could underpin strategic performance improvement, including security. The latter proves challenging for commanders: they cannot easily adjust demand or sourcing.

\section{Exploring the Future of Military Logistics}

We conclude our chapter on military logistics with innovation and challenges.

Innovation Traditionally, military logistics has been impacted by operational innovations aimed at information advantage and coordination and execution of (non) kinetic effects. In an inverse manner, logistics shifts to an innovative-challenging role when it is inclined not to primarily support fuel-consuming energy production systems, but proposes, for instance, alternative energy sources to make bases cheaper, more independent, and more environmentally friendly. Or it can sustain 
special forces with intelligent drones in ways that could inspire new operational concepts.

Future operations are likely to involve multiple domains and focus on critical infrastructures (some without clear geographical sites), symbolic-meaning networks, and urban areas. Success will depend on decision and information superiority across multiple domains of battle.

Challenges Current logistics within military organizations faces internal and external challenges. First, internally, military logistics organizations tend to rely on concept development sequentially following operational concept development. Logistics is understood in terms of fixed concepts and its organization tends to be fragmented across multiple units and shared service organizations. It is focused on reactive, plan-based execution rather than innovation-oriented exchange with strategy, operations, and external partners. Some even state that "civilian logistics has surpassed military logistics" (Rutner et al. 2012). Military organizations struggle with the prolonged time (multiple decades) it takes to develop, acquire, absorb, and use/maintain new technologies, including "soft technologies" such as new logistics concepts developed elsewhere (e.g., last mile logistics concepts). This widens the gap between logistics and the fast-moving operational organization it wants to serve.

Second, externally, logistics innovation involving external partners faces multiple hurdles along the way. Military organizations collaborating with national or international partners may try to bring together latent capabilities (van Fenema and Romme 2020). Yet in reality, they face difficulty when trying to collectively improve networked logistics. Problems include collaboration challenges (Brown and Coryell 2013), turf wars, and problematic learning and mutual adaptation. New concepts do not guarantee success. For instance, efforts to change relationships with suppliers towards Performance Based Logistics suffer from deteriorating performance and control problems (Mahon 2007). Laudable initiatives such as NATO's Operations Logistics Chain Management (OLCM) project struggle with nations' willingness to share logistics information. Despite a so-called collective responsibility, members seem unwilling/unable to change the current national way of doing logistics into a truly collective logistics approach.

All in all, military logistics' innovation and challenges change in the current era with its security, global medical and economics problems, and transformative digital technology. We expect cooperation to proceed in small clusters of nations and organizations, yielding increasingly sophisticated logistics concepts and practices.

\section{Conclusion}

This chapter introduces the practice of military logistics as it relates to commercial logistics, military operational art, and political decision making. These relationships make sense given the conditio sine qua non nature of military logistics for military 
efforts. Military logistics can be viewed as a pragmatic endeavor (which activities are required and how are these organized). To extend this view, this chapter shows process-structure and generic-specific dynamics. Moreover, deep dive themes contextualize military logistics (strategic alignment or what-for questions) and examine the role of supply chain security management in the light of logistics-operations tensions. Our present era seems to stand between historically known kinetic military operations and a still unknown digital future. This transition presents formidable opportunities and challenges for military logistics. Instead of harboring a reactive, servant, and internally oriented stance towards operations of a known structure but with uniquely configured elements, the practice needs to open up and change. Reconsidering its foundational assumptions, relationships, and contributions, military logistics will develop complex predictive capabilities and build networked capabilities. In this process, military logistics will give primacy to the digital realm. Research in military logistics will shift from planning and optimizing towards interdisciplinary studies that marry operations research, analytics, innovation management, and novel forms of organizing inspired by networks, platform, and ecosystems (van Fenema et al. 2021).

\section{References}

Alvesson, M. (1998). The business concept as a symbol. International Studies of Management \& Organization, 28(3), 86-108.

Banian, D. (2013). From hard to harder: Iraq retrograde lessons for Afghanistan. Army Sustainment. http://www.army.mil/article/112409. Accessed 3 April 2015 (October-December).

Boyd, E. B. (2015). Fast Company. http://www.fastcompany.com/3041147/getting-out-ofafghanistan\#!. Accessed 10 April 2015.

Brahimi, L. (2000). The report of the panel on UN peace operations ('Brahimi report'). http://www. un.org/peace/reports/peace_operations/. Accessed 10 April 2015.

Brown, W. A., \& Coryell, B. (2013). Logistics support 'seams' during operations Odyssey Dawn and unified protector. Joint Force Quarterly, 73-77.

Burns, L., Tseng, F., \& Berkowitz, D. (2010). Global network analysis in a military supply chain: Using a systems based approach to develop a next-generation end-to-end supply chain performance measurement and prediction system. Proceedings of the 2010 Cambridge international manufacturing symposium (pp. 23-24).

Caplan, R. (2012). Devising exit strategies. Survival, 54(3), 111-126.

Chan, Y., \& Reich, B. H. (2011). Rethinking business-IT alignment. In B. D. Galliers \& W. L. Currie (Eds.), The Oxford handbook of management information systems. New York: Oxford University Press.

CLM. (1998). Council of Logistics Management. Oak Brook: Council of Logistics Management.

Closs, D. J., \& McGarrell, E. F. (2004). Enhancing security throughout the supply chain. Washington, DC: IBM Center for the Business of Government.

Davids, C., Beeres, R., \& van Fenema, P. C. (2013). Operational defense sourcing: Organizing military logistics in Afghanistan. International Journal of Physical Distribution \& Logistics Management, 43(2), 116-133.

de Bakker, E. (2012). De toekomst van sourcing bij Defensie: Een beschouwing van de voor- en nadelen. Militaire Spectator, 181(12), 551-560.

de Leeuw, S., Vis, I. F. A., \& Jonkman, S. N. (2012). Exploring logistics aspects of flood emergency measures. Journal of Contingencies and Crisis Management, 20(3), 166-179. 
Farrall, J. (2012). Recurring dilemmas in a recurring conflict: Evaluating the UN mission in Liberia (2003-2006). Journal of lnternational Peacekeeping, 16, 306-342.

Filson, D., \& Werner, S. (2004). Bargaining and fighting: The impact of regime type on war onset, duration, and outcomes. American Journal of Political Science, 48(2), 296-313.

Flavin, W. (2007). Planning for conflict termination and post-conflict success. Parameters, 33(3), 95-112.

Fukuyama, F. (2004). Nation-building 101. The Atlantic. http://www.theatlantic.com/magazine/ archive/2004/01/nation-building-101/302862/. Accessed 10 April 2015 (January-February).

Futrell, R. F. (1989). Ideas, concepts, doctrine: Basic thinking in the United States Air Force, 1907 1960 (Vol. 1. Monograph). Alabama: Air University Press, Maxwell Air Force Base. http://oai. dtic. mil/oai/oai verb $=$ getRecord \&metadataPrefix $=$ html\&identifier $=$ ADA588326. Accessed 10 April 2015.

Gallasch, G. E., Lilith, N., Billington, J., Zhang, L., Bender, A., \& Francis, B. (2008). Modelling defense logistics networks. International Journal on Software Tools for Technology Transfer, 10(1), 75-93.

Gans, B. (2019). Stabilisation operations as complex systems - Order and chaos in the interoperability continuum. $\mathrm{PhD}$ Thesis Tilburg University, School of Economics and Management. https://research.tilburguniversity.edu/en/publications/stabilisation-operations-as-complex-sys tems-order-and-chaos-in-th

Gartner, S. S., \& Blanken, L. (2012). Beyond victory and defeat. In H. Rothstein \& J. Arquilla (Eds.), Afghan endgames: Strategy and policy choices for America's longest war. Washington, DC: Georgetown University Press.

Hameri, A.-P., \& Hintsa, J. (2009). Assessing the drivers of change for cross-border supply chains. International Journal of Physical Distribution \& Logistics Management, 39(9), 741-761.

Hampapur, A., Cao, H., \& Davenport, A. (2011). Analytics-driven asset management. IBM Journal of Research \& Development, 55(1, 2), 138-156.

Henderson, J. C., \& Venkatraman, N. (1992). Strategic alignment: A model for organizational transformation through information technology. In T. A. Kocham \& M. Useem (Eds.), Transforming organizations. New York: Oxford University Press.

Hoffman, F. G. (2009). Hybrid warfare and challenges. JFQ (52), 34-48.

Howard, L. M. (2008). UN peacekeeping in civil wars. Cambridge: Cambridge University Press.

Hulsmann, M., Grapp, J., \& Li, Y. (2008). Strategic adaptivity in global supply chains - competitive advantage by autonomous cooperation. International Journal of Production Economics, 114, $14-26$.

Innocent, M., \& Carpenter, T. G. (2009). Escaping the 'graveyard' of empires: A strategy to exit Afghanistan. Washington, DC: White Paper, CATO Institute.

Johnson, D. D. P., \& Tierney, D. (2011). The Rubicon theory of war: How the path to conflict reaches the point of no return. International Security, 36(1), 7-40.

Jomini, A.-H., Mendell, G. H., \& Craighill, W. P. (2007). The art of war. Mineola: Dover. (Jomini's book was originally published in 1862)

Kapucu, N., \& Garayev, V. (2012). Designing, managing, and sustaining functionally collaborative emergency management networks. The American Review of Public Administration, 43(3), 312-330.

Khasis, D. (2020). Coronavirus has global logistics sector reeling. SpendMatters. https:// spendmatters.com/2020/03/23/coronavirus-has-global-logistics-sector-reeling/

Kress, M. (2016). Operational logistics: The art and science of sustaining military operations. Cham: Springer.

Leblanc, J. P. (2008). Theater logistics' important link to transition and exit strategy. Strategy research project, master program, United States Army War College.

Lindley-French, J., \& Boyer, Y. (2012). The Oxford handbook of war. Oxford: Oxford University Press. 
Maas, J.-B., van Fenema, P. C., \& Schakel, J. K. (2014). Business analytics as a method for military organizations. In P. Shields, J. M. M. L. Soeters, \& S. J. H. Rietjens (Eds.), Routledge handbook on research methods in military studies. London: Routledge.

Mahon, D. (2007). Performance-based logistics: Transforming sustainment. Journal of Contract Management, 5(1), 53-71.

Makadok, R. (2001). Toward a synthesis of the resource-based and dynamic-capability views of rent creation. Strategic Management Journal, 22(5), 387-401.

Mangiaracina, R., Perego, A., Seghezzi, A., \& Tumino, A. (2019). Innovative solutions to increase last-mile delivery efficiency in B2C E-commerce: A literature review. International Journal of Physical Distribution \& Logistics Management, 49(9), 901-920.

Markmann, C., Darkow, I. L., \& von der Gracht, H. (2013). A Delphi-based risk analysis identifying and assessing future challenges for supply chain security in a multi-stakeholder environment. Technological Forecasting and Social Change, 80(9), 1815-1833.

Mintzberg, H. (1981). Research notes and communications: What is planning anyway? Strategic Management Journal, 2(3), 319-324.

MoD. (2005). JSP 886 The defence logistics support chain manual, volume 1-part 2, DE\&S SCS, Andover. UK Ministry of Defence. https://www.gov.uk/government/uploads/system/uploads/ attachment_data/file/48865/JSP886_Vol1_Pt2_BlueprintLevel3.pdf

MoD. (2015a). CDS A-400 joint operational logistic instruction, Directorate of Operations. Dutch Ministry of Defense, The Hague.

MoD. (2015b). JDP 4-00 logistics for joint operations, DCDC, Swindon. UK Ministry of Defence.

MoD. (2019). Netherlands defence doctrine. Netherlands Defence Staff, The Hague, June 2019.

Moten, M. (2010). War termination. The proceedings of the war termination conference, United States Military Academy West Point.

Natarajarathinam, M., Capar, I., \& Narayanan, A. (2009). Managing supply chains in times of crisis: A review of literature and insights. International Journal of Physical Distribution \& Logistics Management, 39(7), 535-573.

NATO. (2010). ACO comprehensive operative planning directive, ACO. Brussels: NATO. https:// info.publicintelligence.net/NATO-COPD.pdf

NATO. (2013). AJP-5 allied joint doctrine for operational level planning, NSA. Brussels: NATO. http://www.google.nl/url?url=http://nso.nato.int/nso/zPublic/ap/AJP-5\%2520E.pdf\&rct=j\& frm $=1 \& \mathrm{q}=\& \mathrm{esrc}=\mathrm{s} \& \mathrm{sa}=\mathrm{U} \& \mathrm{ved}=0 \mathrm{ahUKEwj} 6 \mathrm{gI}$.xrKHKAhWMPRQKHaG_ BvAQFggUMAA\&sig2=mfyyq437NNfF2G2YfM8KRA\&usg=AFQjCNGVNKdnJAAYEltp XzyoYbjiJ1jUw

NATO. (2014). AAP-06, glossary of terms and definitions. Brussels: NATO.

Nilsson, F., \& Waidringer, J. (2004). Logistics management from a complexity perspective. The ICFAI Journal of Operations Management, 3(2), 59-73.

O'Hanlon, M. E., \& Sherjan, H. (2010). Toughing it out in Afghanistan. Washington, DC: The Brookings Institution.

Pagonis, W. G. (1993). Moving mountains: Lessons in leadership and logistics from the Gulf war. Boston: Harvard Business School Press.

Perez, H. D. (2013). Supply chain strategies: Which one hits the mark? Supply Chain Quarterly. http://www.supplychainquarterly.com/topics/Strategy/20130306-supply-chain-strategieswhich-one-hits-the-mark/. Accessed 10 April 2015.

Porter, M. E. (1998). Competitive strategy: Techniques for analyzing industries and competitors. New York: Free Press.

Reiter, D. (2009). How wars end. Princeton: Princeton University Press.

Richardson, J. (2009). Deciding on exit strategies: Using foresight in problem resolution. Foresight, $11(2), 50-62$.

Rutner, M., Aviles, M., \& Cox, S. (2012). Logistics evolution: A comparison of military and commercial logistics thought. International Journal of Logistics Management, 23(1), 96-118.

Sabherwal, R., \& Chan, Y. E. (2001). Alignment between business and IS strategies: A study of prospectors, analyzers, and defenders. Information Systems Research, 12(1), 11-33. 
Scholtens, A. (2008). Controlled collaboration in disaster and crisis management in the Netherlands, history and practice of an overestimated and underestimated concept. Journal of Contingencies and Crisis Management, 16(4), 195-207.

Schönsleben, P. (2016). Integral logistics management: Operations and supply chain management within and across companies. Boca Raton: CRC Press.

Seifert, R. W., \& Langenberg, K. U. (2011). Managing business dynamics with adaptive supply chain portfolios. European Journal of Operational Research, 215(3), 551-562.

Selldin, E., \& Olhager, J. (2007). Linking products with supply chains: Testing Fisher's model. Supply Chain Management: An International Journal, 12(1), 42-51.

Sheffi, Y., \& Rice, J. B., Jr. (2005). A supply chain view of the resilient enterprise. MIT Sloan Management Review, 47(1), 41-48.

Sigal, L. V. (2007). A war without end. World Policy Journal, 24(3), 1-7.

Simsek, Z. (2009). Organizational ambidexterity: Towards a multilevel understanding. Journal of Management Studies, 46(4), 597-624. Retrieved from http://amj.aom.org/content/51/3/557. abstract.

Sinno, A. H. (2008). Organizations at war in Afghanistan and beyond. Ithaca: Cornell University Press.

Smith, J. E. (2018). Defence logistics. Bournemouth: Kogan Page.

Smith, W. K., \& Lewis, M. (2011). Toward a theory of paradox: A dynamic equilibrium model of organizing. Academy of Management Review, 36(2), 381-403.

Speed, R. J. (1989). Oh Mr Porter! A re-appraisal of competitive strategy. Marketing Intelligence \& Planning, 7(5/6), 8-11.

Stank, T. P., Daugherty, P. J., \& Ellinger, A. E. (1999). Marketing/logistics integration and firm performance. The International Journal of Logistics Management, 10(1), 11-24.

Strednansky, S. E. (1996). Balancing the trinity: The fine art of conflict termination. Thesis, Air University Press, Maxwell Air Force Base, Alabama.

Thornton, P. H., \& Ocasio, W. (2008). Institutional logics. In R. Greenwood, C. Oliver, R. Suddaby, $\&$ K. Sahlin (Eds.), The Sage handbook of organizational institutionalism. London: Sage.

Tuck, C. (2004). Conflict termination in Iraq. RUSI Journal, 149(5), 17-21.

USArmy. (2011). FM 3-0 operations. Headquarters of the Army, Washington, DC, February 2008.

USArmy. (2012). ADP 3-0, unified land operations. Headquarters of the Army, Washington, DC.

van Creveld, M. (1979). Supplying war: Logistics from Wallenstein to Patton. Cambridge: Cambridge University Press.

van Creveld, M. (2004). Supplying war: Logistics from Wallenstein to Patton. Cambridge: Cambridge University Press.

van Fenema, P. C. (2010). Military organizations and national crisis response. In J. M. M. L. Soeters, P. C. van Fenema, \& R. Beeres (Eds.), Managing military organizations: Theory and practice. London: Routledge.

van Fenema, P. C., \& Keers, B. B. M. (2020). Rediscovering strategic content in 'strong process' research on business network innovation. Industrial Marketing Management, 91, 639-656.

van Fenema, P. C., \& Romme, A. G. L. (2020). Latent organizing for responding to emergencies: Foundations for research. Journal of Organization Design, 9(1), 1-16.

Van Goor, A. R., van Amstel, W. P., \& van Amstel, M. P. (2019). European distribution and supply chain logistics. Routledge.

van Kampen, T., van Fenema, P. C., \& Grant, T. J. (2012). Getting there and back: Organizing longdistance military logistics with customers in mind. In R. M. Beeres, J. van der Meulen, J. M. M. L. Soeters, \& A. L. W. Vogelaar (Eds.), Mission Uruzgan: Collaborating in multiple coalitions for Afghanistan. Amsterdam: Amsterdam University Press/Pallas Publications.

van Kampen, T., van Fenema, P. C., \& Faber, N. (2016). Strategic defense supply chain security management. In R. Beeres, G. Bakx, E. de Waard, \& S. J. H. Rietjens (Eds.), Netherlands annual review of military studies (NL ARMS). The Hague: Asser. 
van Fenema, P. C., T. van Kampen, G. Gooijer, N. Faber, H. F. Hendriks, A. J. Hoogstrate and L. Schlicher (2021). Sustaining Relevance: Repositioning Strategic Logistics Innovation in the Military. Joint Forces Quarterly 101, 59-68.

Wang, E. T. G., \& Wei, H.-L. (2007). Interorganizational governance value creation: Coordinating for information visibility and flexibility in supply chains. Decision Sciences, 38(4), 647-674.

Whalan, J. (2012). Evaluating peace operations: The case of Cambodia. Journal of International Peacekeeping, 16, 226-251.

Wijbenga, H. (2019). The Royal Netherlands Army's recurring logistics problems: A quest for supply chain management maturity. Master Thesis, Netherlands Defence Academy.

WP. (2009). Exit strategies and peace consolidation in state-building operations. Report on Wilton Park conference 965.

Zaum, D. (2012). Exit and international administrations. In R. Caplan (Ed.), Exit strategies and state building. New York: OUP.

Open Access This chapter is licensed under the terms of the Creative Commons Attribution 4.0 International License (http://creativecommons.org/licenses/by/4.0/), which permits use, sharing, adaptation, distribution and reproduction in any medium or format, as long as you give appropriate credit to the original author(s) and the source, provide a link to the Creative Commons license and indicate if changes were made.

The images or other third party material in this chapter are included in the chapter's Creative Commons license, unless indicated otherwise in a credit line to the material. If material is not included in the chapter's Creative Commons license and your intended use is not permitted by statutory regulation or exceeds the permitted use, you will need to obtain permission directly from the copyright holder.

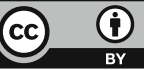

